\title{
Fault lineaments control on disaster potentials in Kulon Progo Mountain Area-Central Java-Indonesia
}

\author{
Asmoro Widagdo ${ }^{1,}$, Subagyo Pramumijoyo ${ }^{2}$, Agung Harijoko $^{2}$, and Agung Setiyanto $^{2}$ \\ ${ }^{1} \mathrm{PhD}$ Program of Geological Engineering, Gadjah Mada University, Yogyakarta, Indonesia \\ ${ }^{2}$ Geological Engineering, Gadjah Mada University, Yogyakarta, Indonesia
}

\begin{abstract}
Many inactive fault lineaments developed in Kulon Progo Mountains, which are mainly composed of Oligo-Miocene age (33,9 - 5,3 million years ago) of volcanic rocks. The directions and distributions of the lineaments differ from one part to another. This research was conducted to reveal the fault lineaments on controlling disaster variation of the area. Fault lineaments delineation is done on the area of all Kulon Progo Mountains. Fault lineaments density variation map is made from the fault lineaments. Fault lineaments density variation map that overlaid by slope map will show the result in a relationship between the fault lineaments density and the potential disaster of the area. The result of fault lineaments density analysis shows that high-density values area tend to be landslide and rock slide at the volcanic rocks. High fault lineaments density with relatively low slope percentage has subsidence potential at limestone area in the central part of Kulon Progo mountains. The disaster tends to happen especially in the area of old rock formation with high fault lineaments density.
\end{abstract}

\section{Introduction}

Research area is located in Kulon Progo Mountain, Central Java - Indonesia (Fig. 1.). The phenomenon of geological structure that develops on the body of the Tertiary age of volcanic rocks can be found in this area. Publication on volcanic geology as well as geological structure in this area has been done by many researchers such as [1-14]. Fault lineaments are very common and show a radial pattern around the body of the Tertiary volcano that still looks quite ideal [2].

Tectonic has controlled the formation of Kulon Progo Mountain [6]. [8] saids that the unique morphology of the Kulon Progo Mountains is caused by the tectonics that has occurred since the Eocene time (56 - 33,9 million years ago). [15] and [16] published NNE-SSW fault lineament as Progo-Muria fault. [17], observes the existence of a transform fault that accommodates East Java's microcontinent shift in Kulon Progo area. [10] mentions that the fault structure found in the Kulon Progo Mountains are the strike-slip and normal fault.

Specific morphological expression of the Kulon Progo Mountain [18] is due to the general trend of tectonics since Eocene time. Normal faults, thrust faults and strike-slip faults [11] control the distribution of rocks in Kulon Progo Mountains area. Joint, fold and fault [12] can be found in the Kulon Progo Mountains. Shear joints, tensional joint, normal fault, thrust fault, strike-slip fault and fold [13] form in Kulon Progo Mountains. Fault develops in the research area is produced by compressional and extensional tectonic phase [14].

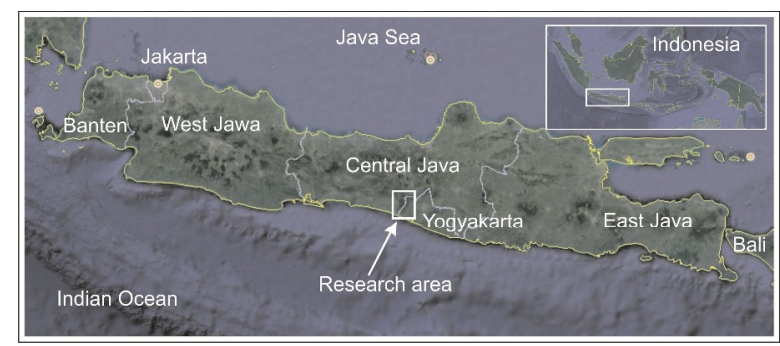

Fig. 1. The Configuration of Research location in Java Island

This article is a result of the research that specifically discusses the fault lineaments and relation to the potential disaster of the area. This research is conducted to find out the correlation of fault lineaments and the density of the lineaments with the disaster that happened in the area.

\section{Regional geology}

Regionally, Kulon Progo is mainly composed of Tertiary volcanic rocks. The Old Andesite Formation (OAF) [1] is the name used for all volcanic rocks in Kulon Progo. Further publications by [3] and [4], dividing Kulon Progo Mountains into 3 parts namely Kebo-Butak Formation, Andesite, and Dacite Intrusion. Through interpretation of the image in this study is known the 
distribution of Gajah, Ijo and Menoreh volcanic body, and the order of its formation.

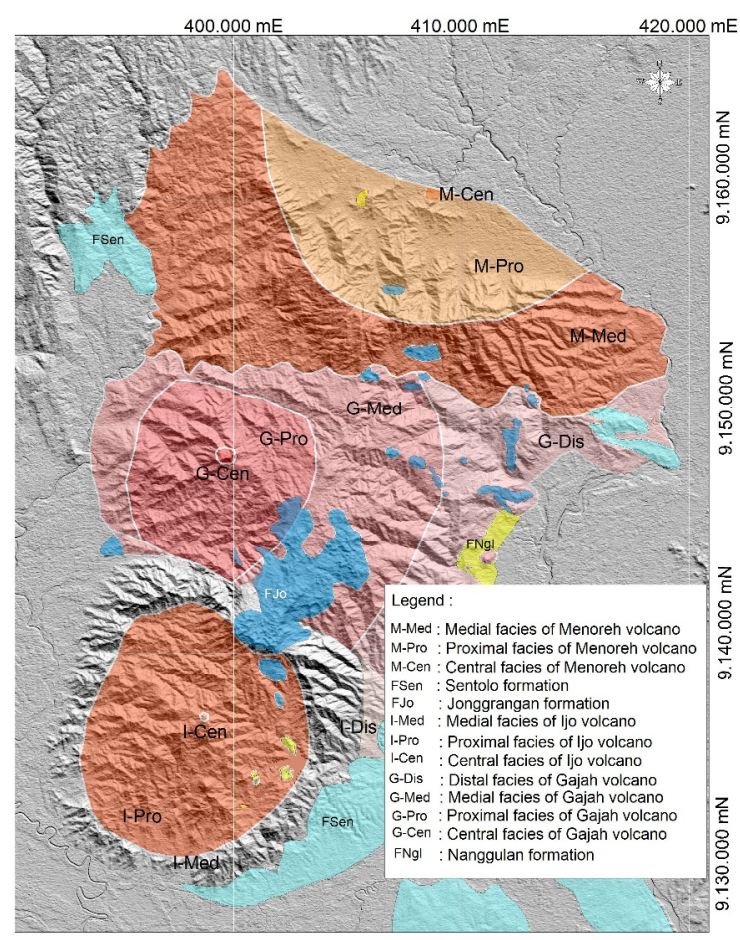

Fig. 2. Volcanic rock facies distribution of three tertiary volcanos

Volcanic body delineation in Fig. 2. shows that Kulon Progo Mountain is composed of three tertiary volcano bodies which is in line with [19]. In the southern part, there is a circular pattern that is still intact from Ijo volcano. This intact circular pattern covers the body of Gajah volcano in the middle of Kulon Progo Mountain. With this cross-cutting relationship, it is certain that Mount Gajah is older than Mount Ijo.

In the North, there is a half-ridged pattern of Menoreh volcano (Fig. 2.). This volcano had collapsed and only half of it remains. The remaining part of this volcano opens to the North. The northern foot of this volcano is located above the body of Mount Gajah. Image analysis with an addition of Jonggrangan Formation rocks shows that Mount Menoreh is overlying on this formation as well. Thus Menoreh volcano is younger than Mount Gajah and Jonggrangan-Sentolo Formations.

Menoreh volcano in the North has no direct connection with Mount Ijo in the South. Both volcanoes are younger than Mount Gajah. The age-sequence relationship between them can be determined by looking at the spread of the Jonggrangan Formation. In the South, the Jonggrangan Formation is above the body of Ijo volcano, while in the North, the Jonggrangan Formation is under Menoreh volcano. Thus the relative age of Ijo volcano is older than Menoreh volcano.

Observation of maps and imagery show that the distribution of rocks of Mount Gajah in the middle of Kulon Progo Mountain is covered by erupted rocks of Mount Ijo. Mount Ijo shows a circular pattern that is still intact, while Mount Gajah is no longer showed this structure (Fig. 2.). This happens because Mount Gajah is closed by the presence of Ijo Mountain rocks. This crosscutting relationship shows that Mount Gajah comes first and then Mount Ijo comes to close some parts of Mount Gajah (Fig. 2.). Almost the entire body of Mount Gajah which includes the medial and distal facies on the south side had been collapsed and covered by the material of Ijo volcano.

The determination of absolute age has been done by [20] and [21]. [20] mentions the age of Mount Gajah is 25.4-29.6 Million years. The age of Mount Ijo rock is between $17.0+2.0$ to $16.0+2.2$ Million years. While Menoreh Mountain according to [19] and [21], is between $11.4+0.7$ to $12.4+0.7$ million years or Upper Miocene.

\section{Method}

The Method used in this research is through image delineation and fieldwork. Delineation of fault alignment is performed on the image of the entire Kulon Progo Mountain. Using the map of fault lineaments, lineament density variation map for every area of one square kilometer $\left(\mathrm{km} \mathrm{/} \mathrm{km}^{2}\right)$ was made. When the fault lineament density variation map being overlayed by slope map, the potential disaster of the area could be identified.

\section{Delineation of fault lineations}

Lineament is a phenomenon on the surface of the earth that exhibits the characteristics of a linear or curvilinear appearance associated with a fault or a weak zone [22]. The straightness of the flow pattern is a common geomorphological expression of lineament. The different types of rocks also allow to giving a contrast appearance to remote sensing imagery observations.

The result of the fault alignments of each volcanic body, as well as the limestone formation of Sentolo and Jonggrangan were 6shown in Fig. 3. In this figure, there are as much as 1,289 fault alignments. These lineaments come from 4 groups of rocks namely Mount Gajah, Mount Ijo, Sentolo-Jonggrangan Formations, and Mount Menoreh. The rose diagram illustrates the percentage of lineaments in each rock group on the left side of Fig. 3.

Gajah volcano area as the oldest volcanic rock group in the Kulon Progo Mountains shows the highest lineaments of 430 pieces or $33.35 \%$ of the entire existing alignment. The number of lineaments is the highest compared to the other rock groups in the Kulon Progo Mountain. The results of the drawing of the roses diagram in left of Fig. 3. resulted in a $39.5 \%$ North West-South East (NW-SE) general direction, East-West (EW) of $12.5 \%$, North-South (NS) of $12.5 \%$ and slightly $10 \%$ at North East-South West direction (NE-SW), as much as $25.5 \%$ spread at other directions. The percentage of lineaments is strongly dominated by North-Western-directed lineaments (NW-SE) of 39.5\%.

Mount Ijo as a second volcanic rock is present in Kulon Progo Mountain, indicating the presence of 345 majors or as many as $26.80 \%$ of the entire fault lineaments in the study area. In the depiction of the rose 
diagram of the straightness (Fig. 3.) gives a $31.5 \%$ (NW$\mathrm{SE})$ general direction, $15.5 \%(\mathrm{EW}),(\mathrm{NE}-\mathrm{SW})$ as much as $14 \%$, and a small number of (NS) as much as $12.5 \%$, as much as $26.5 \%$ spread at other minor directions.

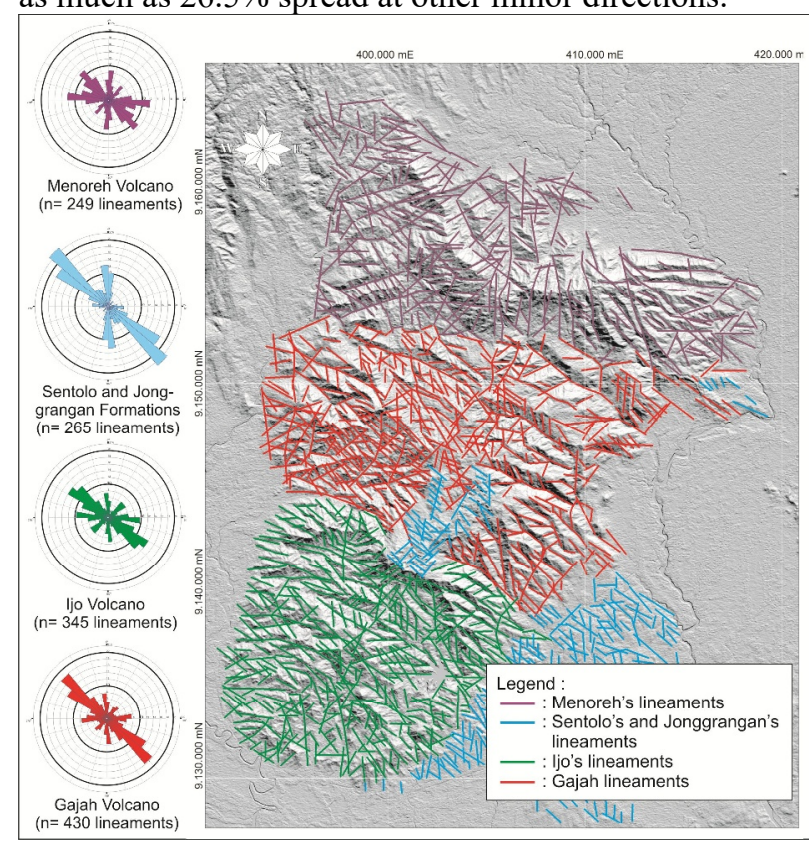

Fig. 3. Interpretation of fault lineaments of each volcano body and sedimentary rocks in the Kulon Progo Mountains.

In Sentolo and Jonggrangan Formations, indicating the presence of lineaments of 265 units or as much as $20.56 \%$ of the total lineaments. In the rose diagram of the lineaments, (left of Fig. 3) gives an overview of the general direction of northwest-southeast (NW-SE) as much as $45 \%$; north-south (N-S) of $22.5 \%$; and a small number of east-west (E-W) of $6.5 \%$, as much as $26 \%$ spread at other minor directions. The percentage of lineaments directions shows the dominant value in the northwest-southeast (NW-SE) direction.

Menoreh volcano as the youngest volcanic rock around the Kulon Progo Mountains shows the presence of fault lineaments of 249 pieces or as much as $19.32 \%$ of the overall fault lineaments. The rose diagram of the fault lineament gives an overview of the general direction of northwest-southeast (NW-SE) as much as $30 \%$, west-east (E-W) as much as $26 \%$, and north-south $(\mathrm{N}-\mathrm{S})$ as much as $14 \%$. There are as much as $30 \%$ spread at other minor directions.

\section{Density of fault lineaments}

Fault lineaments density variation map (Fig. 4.) shows that the number of fault lineaments density is in the range of the fault lineament length $0-6 \mathrm{~km} / \mathrm{km}^{2}$. In the body of Gajah volcano formed several centers of the density range of $5-6 \mathrm{~km} / \mathrm{km}^{2}$ and the spread is wide enough for the density of $4-5 \mathrm{~km} / \mathrm{km}^{2}$ in the northwest. In the body of Ijo volcano, the density range of 4-5 $\mathrm{km} / \mathrm{km}^{2}$ and the distribution of density $5-6 \mathrm{~km} / \mathrm{km}^{2}$ formed in the middle of the volcanic body. At the body of Menoreh volcano, densities of $4-5 \mathrm{~km} / \mathrm{km}^{2}$ and 5-6 $\mathrm{km} / \mathrm{km}^{2}$ formed in the north and west of the volcano

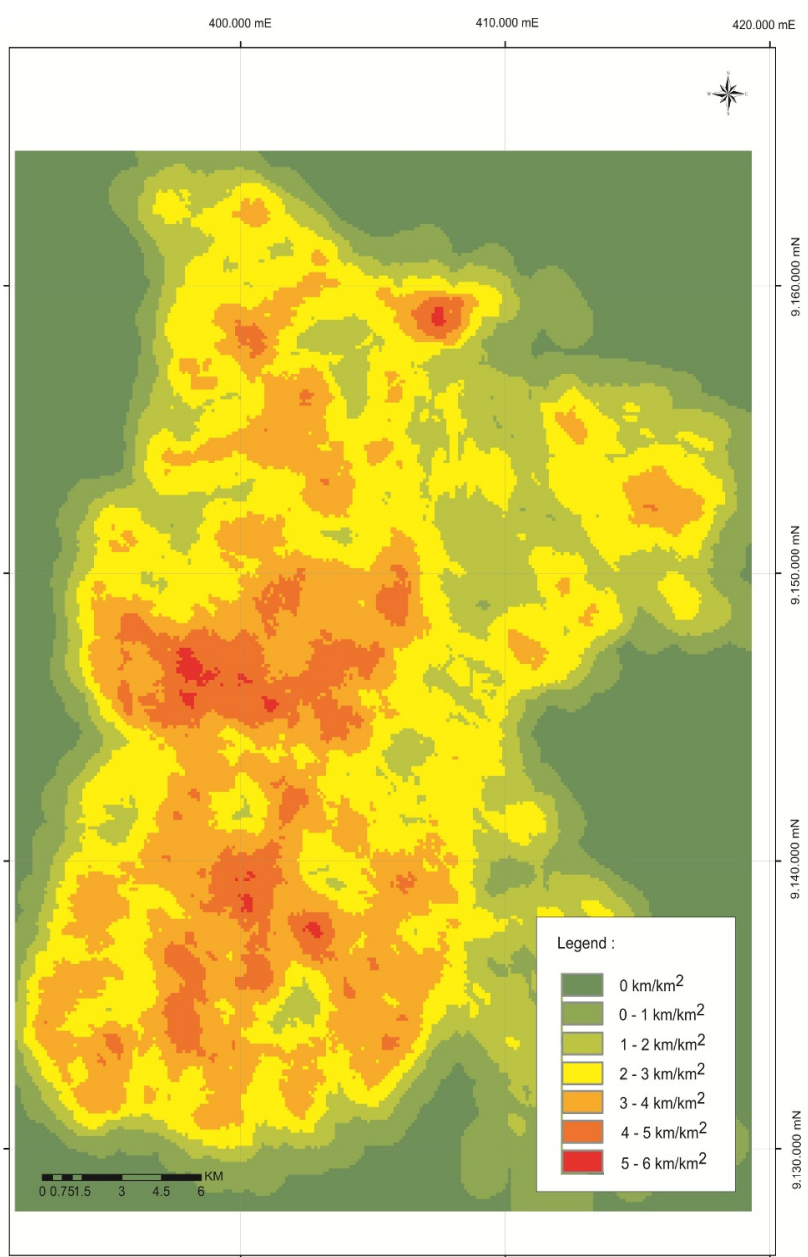

Fig. 4. Lineaments density variation map

Fault lineament density value of $0-1 \mathrm{~km} / \mathrm{km}^{2}$ is mainly developed in volcano-clastic rocks and sedimentary rocks on the eastern side of Kulon Progo Mountain. This area is composed of sandstone tuff, claystone, siltstone, conglomerate which is distal facies of Gajah volcano. Limestone layered, thick marl, siltstone, calcareous sandstone which is a rock of Sentolo Formation and also claystone, sandstone and marl of Nanggulan Formation compose the eastern side of this Kulon Progo Mountain. The bending nature of these sediments in accommodating tectonic forces further forms ductile deformation. The geological structure formed in this deformation is the fold, both anticlines, and synclines. Less intensive joint and fault structures are formed in this rock group area.

The density of $1-2 \mathrm{~km} / \mathrm{km}^{2}$ mainly develops on the medial facies section of the Tertiary volcano. This area is mainly composed of tuffaceous breccia, andesite breccia, agglomerate, tuffaceous sandstone, conglomerate, siltstone and a thin layer of lava. The volcanostratigraphy of rocks in this area shows a combination of ductile and brittle properties. Thus the fold structure still forms in this area, especially in claystone, conglomerate, clayey sandstone. The joint and fault structures also form on compact rocks such as tuffaceous sandstone and lava. The density of $2-3 \mathrm{~km} / \mathrm{km}^{2}$ mainly develops in the proximal-medial part of the Tertiary volcanic body. This area is mainly composed of dominant andesite breccia, tuffaceous breccia, agglomerate, fragmental sandstone, 
clayey sandstone and a thin of lava. The Vulcanostratigraphy of rocks in this area shows a combination of ductile and brittle properties. Thus the fold structures are still formed in this area especially in the clayey sandstones. The joint and fault structures also form on compact rocks such as sandstones and lava.

Lineament density of $3-4 \mathrm{~km} / \mathrm{km}^{2}$ mainly develops in the proximal facies of the three tertiary volcano bodies. This area is mainly composed of dominant lava and volcanic breccia. The volcano-stratigraphy of rocks in this area indicates a brittle deformation. Thus the fold structure is not formed in this area. Intensive joint and fault structures are formed on compact rocks, such as in andesite/dacite intrusions, and andesite/basal lava.

The lineament density between $4-6 \mathrm{~km} / \mathrm{km}^{2}$ develops in the middle of the three Tertiary volcanoes. This section is composed of basaltic lava, andesitic lava, andesite intrusive rock, and dacite intrusive rock. This area is part of the central-proximal facies of each Tertiary volcano body in the Kulon Progo Mountains. All of the rocks in this facies are brittle in response to deformation due to tectonic forces that have occurred. Thus the rocks will be more likely to break if there is a tectonic force. Thus the joints and fault structures are very abundant in this section.

High lineament density usually followed by intense alteration and mineralization. In turn, intense soil formation occurs in this zone. Its mainly happened in the central-proximal facies of the three volcanic bodies.

\section{Slope analysis}

Slope values map (Fig. 5.) shows 7 slope intervals in percentage $(\%)$. The green colour is a relatively flat area (0-5 \%) around Kulon Progo Mountain. It consists of alluvial deposits with material came from Kulon Progo mountain, Merapi volcano, Sumbing volcano, and sand.

Slope value $5-10 \%$ can be found in the central area of Kulon Progo mountains. This area consists of limestone as a part of Jonggrangan Formation. Morphologically this area forms a karst with conical hills.

Slope value $10-20 \%$ can be found in the central area of Ijo volcano in the southern Kulon Progo mountains. This area consists of lava and andesite breccia as a part of Old Andesite Formation. This area is a hilly area controlled by fault structures and intensive rock alterations.

Slope value $20-30 \%$ shown by yellow colour can be found in all area of Kulon Progo mountains. This slope is very dominant in the research area except in the central area. This interval can be found at all type of volcanic rocks and all volcanic body.

Slope value $30-40 \%$ is shown by orange colour can be found at the northern, western and eastern area of Kulon Progo mountains. This slope is not too dominant in the research area. This interval found at lava, andesite intrusion and andesite breccia rocks of all volcanic body especially in the inner part of the volcano.

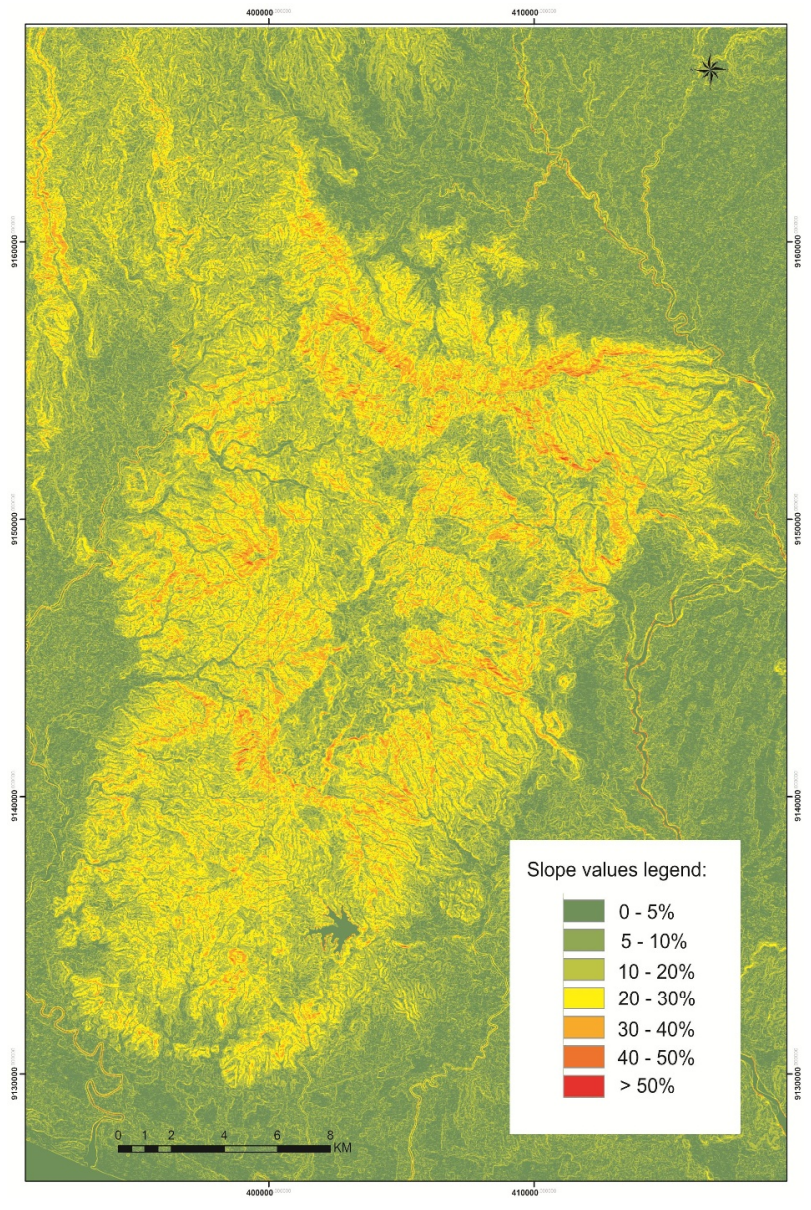

Fig. 5. Slope values map of Kulon Progo area

Slope value $40-50 \%$ can be found at the northern, western and eastern part. This slope is very minor in the research area. This interval found at lava and andesite breccia rocks of all volcanic body especially in the inner part of the volcano.

Slope value more than $50 \%$ can be found at northern, western part of the research area. This slope is very minor in the research area. This interval found at andesite intrusion, andesite lava and andesite breccia rocks of Gajah and Menoreh volcano.

\section{Discussion}

Fault lineaments show high density at the inner part of the Gajah, Ijo, and Menoreh (Fig. 4.). Gajah volcano as the oldest volcanic rock (Fig. 2.) records the highest density of fault lineaments. The east part of Gajah volcano shows a rare fault lineament (Fig. 3. and Fig. 4.), different from the western part of the volcano. The Western part of Gajah volcano is an inner facies (central and proximal). Eastern part of Gajah is a medial and distal facies volcano (Fig. 2.). They have a different type of rock. Different rock types and lineaments intensity give differences of erosion intensity. Landslides tend to be happening in the western part of Gajah volcano. Thick soil and intense alteration are the results of intense fault and fracture or the rock. 
The central map is a central Gajah volcano which overlain by limestone of Jonggrangan Formation (Fig. 2.). It shows a relatively flat and moderate hill with high fault density (Fig. 4.). This area tends to subside because of the cave below the surface. It is happening this year in front of Kiskendo cave.

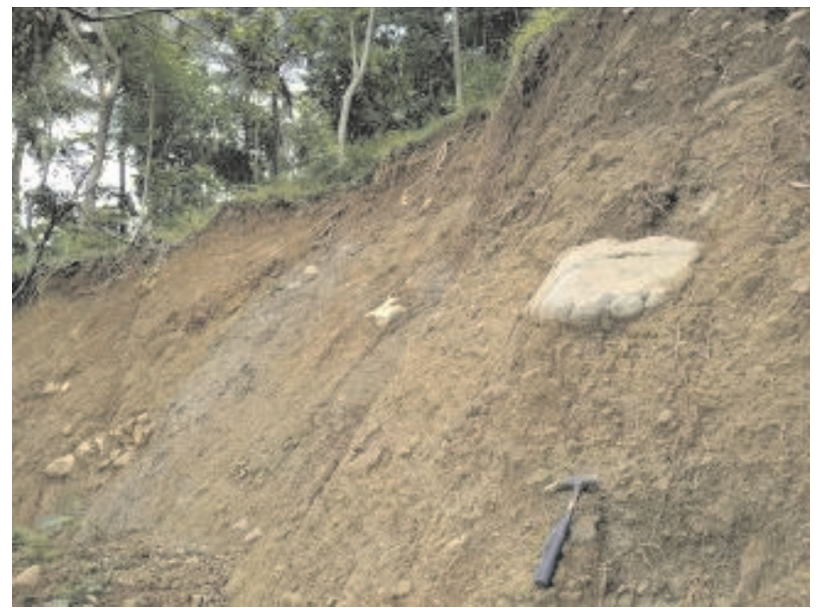

Fig. 6. Rockslide potential at the fresh andesite breccia formation with intense fault lineament and high slope value.

Ijo volcano at the southern part shows high slope at the north part (Fig. 5.). The ring of andesite volcanic outer the volcano is a medial facies. The north part of the area shows a lot of landslide spots. Some intrusion bodies at central and proximal facies show high fault density and high slope. There are thin soil formations at these parts as the slope is too high. Rockfall is tending to happen in these high slope areas.

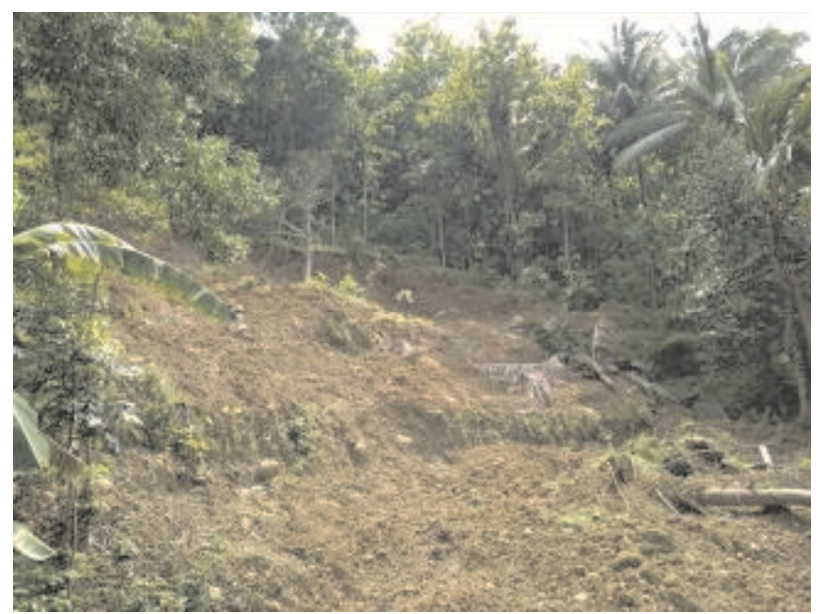

Fig. 7. Landslide at the intense weathered-altered andesite breccia formation with high percentage slope value and high fault density.

Menoreh volcano at the northern part of Kulon Progo mountains area shows a long of the fault scarp. It shows a high to medium fault density with a high slope at the lava and volcanic breccia. Since the soil is very thin and the slope is very steep, rock fall tends to happen in the fault scarp area. It happens especially at the dip slope of the rock formations.

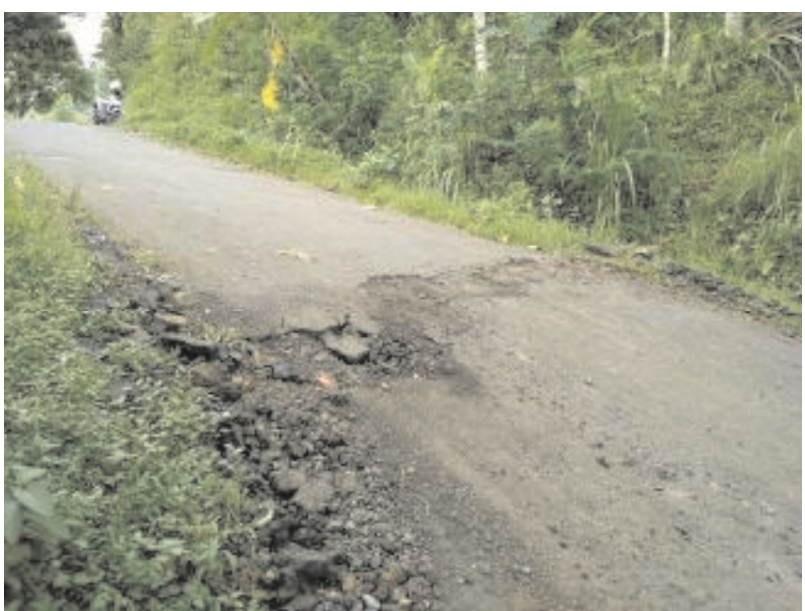

Fig. 8. Subsidence at the high fault density of limestone area with low slope values, because of the cave below the surface.

\section{Conclusions}

Fault lineaments show high density at the inner part of the oldest volcanic rock. Slope values show low value at the young rock or alluvial deposits and outer faces of volcanic rock. High slope value tends to be formed at the high lineament density at the lava or andesite breccia rocks. This area with fresh rock condition tends to be rock slide and at altered or weathered rock tend to be a landslide. Limestone with intensive fault lineament tends to be subsiding

This publication of the research can be completed with help of various parties. The expression of gratitude to the Ministry of Higher Education, which has provided scholarships to fund the research. Acknowledgements also to Dr. Gayatri I.M., Dr. Didit H.B., AAng PP, and Yan R.F. are very helpful for writing this paper.

\section{References}

1. Van Bemmelen, R.W., The Geology of Indonesia. Vol. IA, General Geology of Indonesia and Adjacent Archipelago, Government Printing Office, The Hague. (1949)

2. Suroso, Rodhi, A., dan Sutanto, Proposed Adjustment of the Name of Litostratigrafi Kulon Progo, Yogyakarta Special Region. Collection of Papers for the XV Annual Scientific Meeting of the Indonesian Geological Association, Volume 1, IAGI-Yogyakarta (1987)

3. Rahardjo, W., Sukandarrumidi, Rosidi, HMD., Yogyakarta Sheet Geological Map. Geological Research and Development Center, Bandung (1995)

4. Rahardjo, W., Sukandarrumidi, Rosidi, HMD., Yogyakarta Sheet Geological Map. Geological Survey Center - Geological Agency - Ministry of Energy and Mineral Resources (2012)

5. Bronto, S., 2006. Volcanic Facies and Applications. Indonesian Journal of Geology, Vol. 1 No. 2.. 
6. Budiadi, E., 2009, The Role of Tectonism in Controlling Geomorphology in Kulon Progo Area, Yogyakarta, Proceedings PIT IAGI Semarang, The $38^{\text {th }}$ IAGI Annual Conventional and Exhibition

7. Barianto, D.H., Kuncoro, P., Watanabe, K., The Use of Foraminifera Fossils for Reconstructing the Yogyakarta Graben, Yogyakarta, Indonesia. Journal of South East Asian Applied Geology, May-August 2010, Vol 2(2), pp 138-143 (2010)

8. Sudradjat, A., Syafri, I., dan Budiadi, E., The Geotectonic configuration of Kulon Progo Area, Yogyakarta. Proceeding PIT IAGI Lombok 2010, The $39^{\text {th }}$ IAGI Convention and Exhibition, Lombok (2010)

9. Harjanto, A., Vulkanostratigrafi in the Kulon Progo Region and its surroundings, Yogyakarta Special Region. MTG Scientific Journal, Vol. 4 No. 2, Yogyakarta (2011)

10. Wijono, S. dan Haryoprasetyo, H., The Influence of Hydrothermal Alteration in the Land Formation Process for the Making of Zonation of Vulnerability of Land Movement in PurwosariKebonharjo Region, Girimulyo-Samigaluh District, Kulon Progo Regency, Yogyakarta. Proceedings of the 4th National Seminar on Earth Sciences, Geological Engineering, FT-UGM, UGM, Yogyakarta (2011)

11. Widagdo, A, Pramumijojo, S., Harijoko, A., Setiawan, A., Preliminary Overview of the Character, Patterns, and Styles of The Geologic Structure of Kulon Progo Mountains Area and Its Potential as a Source of The Geological Structural Damage. Proceedings International Conference Jogja Earthquake in Reflection, Universitas Pembangunan Nasional, Yogyakarta (2016)

12. Widagdo, A, Pramumijojo, S., Harijoko, A., Setiawan, A., Type, Pattern and Force Direction of the Geological Structure At Kulonprogo AreaYogyakarta-Indonesia. The $6^{\text {th }}$ International Annual Engineering Seminar (InAES), Yogyakarta (2016)

13. Widagdo, A, Pramumijojo, S., Harijoko, A., Setiawan, A., Preliminary Study Controls the Geological Structure of the Distribution of Rocks in the Kulon Progo-Yogyakarta Mountains. Proseiding the 9th National Seminar, T. Geologi UGM, Yogyakarta (2016) (In Indonesia)

14. Widagdo, A, Pramumijojo, S., Harijoko, A., Reconstruction of the Geological Structure of the Gunung Ijo Region in the Kulon Progo-Yogyakarta Mountains Based on the Sturdy Spread and Quartz Veins. Proseiding the 10th National Seminar, T. Geologi UGM, Yogyakarta (2017) (In Indonesia)

15. Hall, R., Clements, B., Smyth, H.R., Cottam, M. A., 2007. A New Interpretation Of Java's Structure. Proceedings, Indonesian Petroleum Association, May, 2007.

16. Smyth, H., Hall, R., Hamilton, J., Kinny, P., East Java: Cenozoic Basins, Volcanoes, And Ancient Basement. Proceedings Indonesian Petroleum Association, Thirtieth Annual Convention and Exhibition (2005)
17. Husein, S., dan Nukman, M., Reconstruction of Microcontinent Tectonics in the Southern Mountains of East Java: A Hypothesis based on Ancient Magnetic Analysis. Proceedings of the 8th National Geographic Seminar, FT-UGM, Yogyakarta. .(In Indonesia)

18. Syafri, I., Budiadi, E. dan Sudrajad, A., Geotectonic Configuration of Kulon Progo Area, Yogyakarta. Indonesian Journal of Geology, Vol. 8 No. 4. (2013)

19. Barianto, D.H., Abboud, E. and Setijadji, L.D., Structural Analysis using Landsat TM, Gravity Data, and Paleontological Data from Tertiary Rocks in Yogyakarta, Indonesia. Memoirs of the Faculty of Engineering, Kyushu University, Vol.69, No.2. (2009)

20. Soeria-Atmadja, R., Maury, R.C., Bellon, H., Pringgopawir, H., Polves, M., and Priadi, B.,. Tertiary Magmatic Belts In Java, Journal of Southeast Asian Earth Sciences. Vol 9, No.1. (1994)

21. Akmaluddin, Setijadji, D.L., Watanabe, K., and Itaya, T., New Interpretation on Magmatic Belts Evolution During the Neogene-Quarternary Periods as Revealed from Newly Collected K-Ar Ages from Central-East Java, Indonesia. Proceedings Joint Convention Surabaya-HAGI-IAGIPERHAPI, The $30^{\text {th }}$ HAGI, The $34^{\text {th }}$ IAGI, and The $14^{\text {th }}$ PERHAPI Annual Conference and Exhibition, Surabaya (2005)

22. Sabins, F.F., Remote Sensing Principles and Interpretation, $3^{\text {rd }}$ edition, New York, 93 pp 